\title{
Measuring Banks Service Attitude: An approach to employee and customer acuities
}

\author{
Agha Tahir Ijaz ${ }^{1}$, Asghar $\mathrm{Ali}^{2}$ \\ ${ }^{I}$ Principal, Punjab Group of Colleges - Lahore, Pakistan \\ ${ }^{2}$ Manager, Research \& Development Centre, Punjab Group of Colleges - Lahore, Pakistan
}

\begin{abstract}
Service quality a reflection of organizational performance is known as ultimate measure of customers satisfaction especially in the services sector which retains customers for life. The purpose of this study was to measure banks service attitude by assessing employees and customers perceptions of Pakistani banks. A convenience sampling technique was used in which a spectrum of 200 customers and 100 employees of sampled banks participated in the survey. A five dimensional instrument SERVQUAL adapted from relevant studies was used to measure service attitude of Pakistani banks which was found reliable at 0.8213 Cronbach's alpha, Mean scores, alphas, and Independent samples t-test was used for significance, and variance analysis. Results revealed that significance difference of opinion was found between the perceptions of employees and customers in all the dimensions of service quality which depicts serious initiatives are needed to develop service quality attitude by the Pakistani banks in order to ultimate survival in the banking sector of Pakistan which is very dynamic and competitive.
\end{abstract}

Keywords -Banks, Customers Perceptions, Employees Perceptions, Service Attitude, Service Quality

\section{Introduction}

Banks play a pivotal role in the uplift of economic realm of any country by providing a financial infrastructure in the services sector. In Pakistan banking sector has achieved remarkable growth in the recent decade and explored new horizon of services and induction of many new financial products into the Pakistani market. An escalate increase in the number of banks operating in Pakistan in the last ten years entered banking sector into competitive market in which every bank is trying to get maximum market share. In the race of owing maximum market share banks are facing à serious service quality challenge and trying to provide best quality services from the last few years. Initially banks were lacking service attitude but due to rapid increase and advancement in the banking services, the concept of customer services has been changed and now customer centred approaches are prevailing in order to retain customers for life. Banks have realized the true value of customer and introducing customer driven services in the Pakistani market for a longer survival. Banks could compete with rivals in financial products, offering flexible timings, low credit interest rate and high deposit return but offering quality customer services is the competitive advantage to those banks which offered best quality services because now customers are well known about their rights and every one wants to be provided with best services by their banks. To meet customers expectations in exchange to the price they pay and retain competetitive edge is merely a real challege to the Pakistani bankers because customers learn from their experience and if their level of service expectations decreases it affets customers satisfaction [1]. Studies also reveal that high customer satisfaction also leads to high profitability of the organization [2]. Service quality is consequently studied in the studies as a major construct of customer satisfaction and revealed that its the customer satisfaction that affects the success and performance of any organization [3]. In this perspective, customers perception regarding service quality of bak is very important.

Therefore, the purpose of this study was to measure Pakistani banks service attitude by assessing the perceptions of banks employees and customers. An approach which depicts actual picture of service quality as perceived by employees and customers. This study revealed the perceived difference of opinion of banks employees about service quality they offer and then opinion of customers how they actually perceive service quality of Pakistani banks. Findings are significant for the Pakistani banks to improve their service quality approaches and to build new service standards according to contemporary market practices and to train their employees who could provide customer expected services and banks with highly responsive employees facilitate to create strong customer bondage [29] and banks need to improve employees related attributes of service quality [30], especially managers should focus their attention on service quality because it matters most to customers [36].Finally, it would be significant for the policy makers, and marketers of banking industry to make and implement customer oriented service quality strategies. 


\section{Review Of Relevant Literature}

Banks are facing lot of competition due to increased globalization, technological enhancement and consumer awareness about their rights, this phenomenon has put the banks to think and revise their service quality [8] and especially for the growth and development of service sector [13]. Service quality is an important factor that affects organizational performance, success and ultimate survival in the banking sector [4] and high service quality also increases customer satisfaction and loyalty and customer satisfaction can effects customers future intentions and service quality was also found the basic factor that affects customers satisfaction $[5,14,22$, $23,26,27$ ] and customers are the most important stakeholders in service industries [27]. Initially, quality was associated with tangibles products only because of the low prominence of services sector in the economy, but now due to escalate growth of services sector like banks this concept has earned much importance[15] and many empirical studies have been conducted on banking service quality by using SERVQUAL instrument developed by Parasuraman, et al., [6].

Service quality is a multi-construct concept and has been defined as measure of excellence, conformance to requirements [16], fitness for use [15], and to deliver service and products as expected by the customers in the services sector $[7,15]$. Different perspectives of service quality have been studied by researchers like Parasuraman et al., $[6,11,12]$ developed an instrument having five dimension consisted of 22items to measure service quality, dimensions are, tangibles, reliability, responsiveness, assurance and empathy, and Ramaswamy [17] presented three constructs to measure service quality, these are service performance, customer perceptions, and financial measures.

Kazi [32] found that there is a positive relationship between service quality attributes and customers' satisfaction, a study based in Bangladesh and also supported by [28, 38], a comparative study of Islamic and conventional banks in Pakistan. Service quality is an important and emergent strategy in the marketing and it provides strong basis to maintain competitive position and market share [26]. Yong [18] analyzed definitions of service and presented these types of service which are important to know the concept of service quality. It is a performance; it develops by interacting customers and service suppliers $[17,19,20]$ and another factor is physical resources along with requirement oriented service to customers [21]. Concept of service quality got remarkable intention and debate started because of its measurement difficulties, and no consensus could emerge [24] but it was found that organizations offering high service quality got competitive advantage over other similar firms [25].Results revealed that financial performance measures, interest margin, expense/income, and return on assets have strong correlation with service quality [37]. Service quality is considered an essential part of modern business concern and even in manufacturing industry; entrepreneurs are adding service features to their products because of intense competition [29]. In the current decade, the banking environment throughout the world has emerged into globalization and innovative practices due to certain basic factors like technology [15]. Banks now have realized that delivery of good service quality is highly associated with customers' satisfaction, complaint reduction, bank preferences and brand loyalty [7] and bank selection by the customers' is also affected by the service quality [35]. Customers' perceptions are much important especially in the banking sector because of their high involvement in the operations and service delivery [31] and difference between expectations and perceptions have long term implications for online banks [33]. A study conducted by [34] showed that mostly customers are satisfied from the performance and services of conventional banks in Pakistan but that was to explore awareness level of people towards Islamic banking.

Much research is done before on different aspects of service quality in the banking sector, most of the studies in Pakistan focused customers' perceived difference approach only, but this study approaches differently by getting customers' perceptions about service quality of banks as well as banks employees' perceptions about service quality which they offer, the difference between the customers, and employees acuities depicts the grey area which banks needs to improve urgently because that is the actual picture of the service quality offered by employees' and how actually, customers' perceived it.

This study presided the following research questions based on research objectives.

i. What are the perceptions of customers' and employees' regarding service quality of Pakistani banks?

ii. Is there any significance difference of perceptions regarding service quality of Pakistani banks?

iii. Is there any significance difference of perceptions regarding service quality of Pakistani banks in terms of background variables?

\section{Study Design}

This empirical study was descriptive in nature and a survey was conducted on banks employees and customers in Pakistan to get their perceptions about service quality attitude. A pilot testing was done to ensure the reliability of the instrument which also helped to researchers to amend some questions in the questionnaire which respondents felt difficult to understand and many other issues regarding study was tried to improve as per respondents' opinions in the pre-testing stage of the study. An instrument used to measure service quality was adapted from Parasuraman $[9,10,11,12]$ and developed through 5 point likert rating scale containing five 
dimensions of service quality, which are tangibles, refers to physical facilities, accessories, physical communication material and other equipment; reliability, refers to perform promised services regularly and perfectly; responsiveness, refers to willingness of employees along with quick service delivery; assurance, refers to knowledge and courtesy of staff; and finally, empathy dimensions, refers to caring and individualized attention of customers by the staff. The likert scale ranging strongly agree to strongly disagree was defined as 5 as strongly agree; 4 agree; 3 partially agree; 2 disagree; and 1 was defined as strongly disagree. In the questionnaire statement 1 to 4 measures tangibles; statement 5 to 9 measures reliability; statement 10 to 13 measures responsiveness; 14 to 17 measures assurance; and 18 to 22 measures service quality in terms of empathy. On the pattern of the likert scale ranging from 1 to 5 , this study assumed higher the level of agreement with service quality dimensions, tangibles, reliability, assurance, responsiveness, and empathy, there would be lower need of service quality improvements by the Pakistani banks and vice versa, as depicted in the figure 1 below.

Figure 1; Service quality perceptions vs. Degree of Need for Improvement

\begin{tabular}{|l|l|l|l|l|l|l|l|l|l|}
\hline$\longleftarrow$ & \multicolumn{3}{|c|}{ Level of Employees' \& Customers' Perceptions } & \multicolumn{2}{c|}{$\longrightarrow$ Very High } \\
\hline Strongly Agree & 5 & Agree & 4 & Partially Agree & 3 & Disagree & 2 & Strongly Disagree & 1 \\
\hline Very Low & Need for Service Quality Improvement by the Banks'
\end{tabular}

(Figure 1, concept is taken from Raza \& Naqvi [39])

Target population of this study was all the banks operating in the city of Lahore; list was taken from the official website of the State Bank of Pakistan, five banks were selected randomly and names of banks were promised to respondents to be kept anonymous, and then data were collected from 5 sampled banks employees, 20 employees from each bank, total employees 100, and 40 customers from each banks conveniently, total customers 200, target branches of banks were conveniently selected and approached to administer questionnaire, by the researchers and reliable reference based resources were also used for data collection, data were collected in the duration of 2 months.

Table1; Reliability measures for service Quality Dimensions

\begin{tabular}{|c|c|c|}
\hline \multirow{2}{*}{ Service Quality Dimensions } & \multicolumn{2}{|c|}{ Cronbach's Alpha Value } \\
\cline { 2 - 3 } & Pre-Testing & Complete Study \\
\hline Tangibles & 0.7634 & 0.7988 \\
\hline Reliability & 0.7344 & 0.7586 \\
\hline Responsiveness & 0.7323 & 0.7833 \\
\hline Assurance & 0.6973 & 0.7231 \\
\hline Empathy & 0.7122 & 0.7433 \\
\hline
\end{tabular}

Table 1, shows the reliability score of service quality dimensions of pre-testing and complete study, all the dimensions are above acceptable value of Cronbach's alpha, which is above 0.60 .

\section{Framework Of The Study}

Figure 2; Schematic Diagram

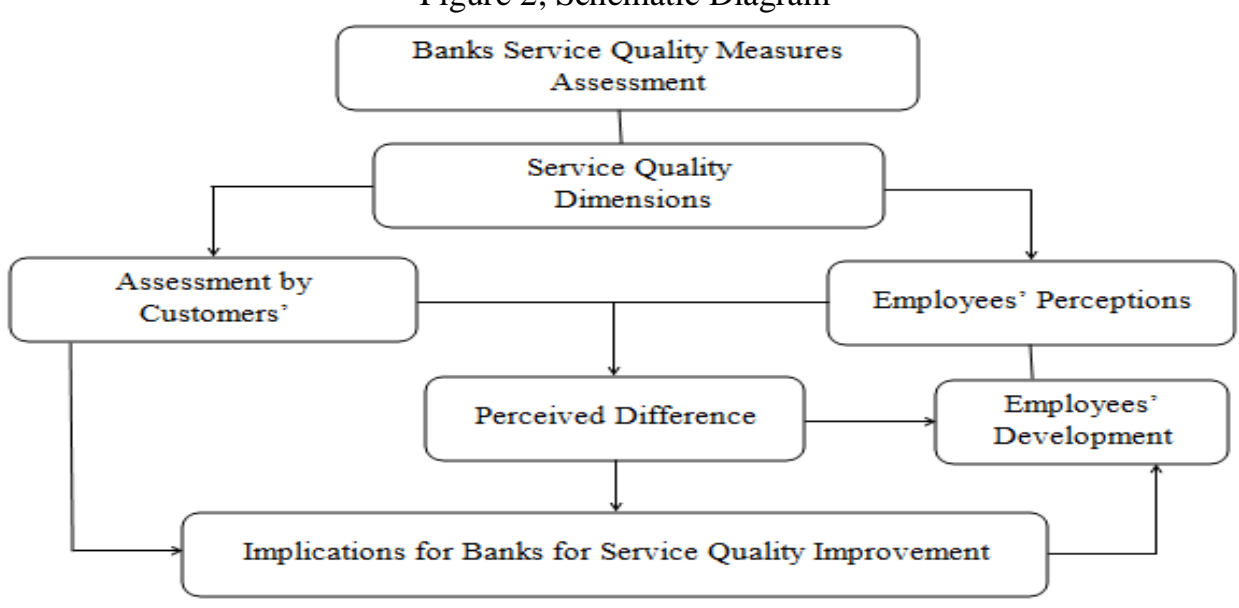

www.iosrjournals.org 


\section{Data Analysis And Results}

A total of 275 respondents participated in the survey, representing $91.67 \%$, which was found reasonable rate, and out of which 190 were customers from total of 200, and 85 employees from total of 100 . Total customers response rate was $95 \%$ and employees' response rate was $85 \%$. Other demographics of the sample are given below.

Table; 2 Demographics Profile of Customers'

\begin{tabular}{|c|c|c|c|}
\hline Demographics & Categories & Frequency & Percentage (\%) \\
\hline \multirow{2}{*}{ Gender } & Male & 180 & 94.7 \\
& Female & 10 & 5.3 \\
\hline \multirow{5}{*}{ Age } & 20 and Below & 5 & 2.6 \\
& $21-30$ & 106 & 55.8 \\
& $31-40$ & 52 & 27.4 \\
& $41-50$ & 20 & 10.5 \\
Affiliation with Bank & 50 and Above & 7 & 3.7 \\
& $0-5$ Years & 108 & 56.84 \\
& $6-10$ & 55 & 28.94 \\
& $11-15$ & 20 & 10.55 \\
Account Type & Above 15 & 7 & 3.67 \\
& Current A/C & 82 & 43.2 \\
& PLs A/C & 96 & 50.5 \\
& Student & 9 & 4.7 \\
& Other & 3 & 1.6 \\
\hline
\end{tabular}

Table; 3 Demographics Profile of Bank Employees'

\begin{tabular}{|c|c|c|c|}
\hline Demographics & Categories & Frequency & Percentage (\%) \\
\hline \multirow{2}{*}{ Gender } & Male & 68 & 80 \\
& Female & 17 & 20 \\
\hline \multirow{4}{*}{ Age } & 20 and Below & 0 & 0 \\
& $21-30$ & 48 & 56.5 \\
& $31-40$ & 22 & 25.9 \\
& $41-50$ & 13 & 15.3 \\
& 50 and Above & 2 & 2.4 \\
\hline \multirow{3}{*}{ Banking Experience } & $0-5$ Years & 41 & 48.2 \\
& $6-10$ & 18 & 21.2 \\
& $11-15$ & 15 & 9.4 \\
\hline \multirow{3}{*}{ Qualification } & Above 15 & 8 & 15.3 \\
& & 13 & 83.5 \\
& Graduation & 71 & 1.2 \\
\hline
\end{tabular}

Table; 4 Independent Samples t-Test for comparison of Service Quality Dimensions by Customers' and Employees'

\begin{tabular}{|c|c|c|c|c|c|c|c|}
\hline $\begin{array}{c}\text { S.Q } \\
\text { Dimensions }\end{array}$ & Respondents' & $\mathrm{N}$ & Mean & SD & MD & t-values & Sig.(2-tailed) \\
\hline \multirow{2}{*}{ Tangibles } & Customers & 190 & 3.801 & 0.592 & \multirow{2}{*}{-0.428} & \multirow{2}{*}{-5.551} & \multirow{2}{*}{$0.000^{*}$} \\
\hline & Employees & 85 & 4.229 & 0.510 & & & \\
\hline \multirow{2}{*}{ Reliability } & Customers & 190 & 3.636 & 0.513 & \multirow{2}{*}{-0.614} & \multirow{2}{*}{-8.242} & \multirow{2}{*}{$0.000 *$} \\
\hline & Employees & 85 & 4.251 & 0.509 & & & \\
\hline \multirow{2}{*}{ Responsiveness } & Customers & 190 & 3.453 & 0.433 & \multirow{2}{*}{-0.766} & \multirow{2}{*}{-8.418} & \multirow{2}{*}{$0.000 *$} \\
\hline & Employees & 85 & 4.220 & 0.520 & & & \\
\hline \multirow{2}{*}{ Assurance } & Customers & 190 & 3.852 & 0.430 & \multirow{2}{*}{-0.332} & \multirow{2}{*}{-3.890} & \multirow{2}{*}{$0.000 *$} \\
\hline & Employees & 85 & 4.185 & 0.432 & & & \\
\hline \multirow{2}{*}{ Empathy } & Customers & 190 & 3.590 & 0.558 & \multirow{2}{*}{-0.593} & \multirow{2}{*}{-7.580} & \multirow{2}{*}{$0.000 *$} \\
\hline & Employees & 85 & 4.183 & 0.456 & & & \\
\hline
\end{tabular}

$* \mathrm{p}<0.05$ 
Measuring Banks Service Attitude: An approach to employee and customer acuities

Table; 5 Independent Samples t-Test for comparison of Service Quality Dimensions by Gender (Customers)

\begin{tabular}{|c|c|c|c|c|c|c|c|}
\hline $\begin{array}{c}\text { S.Q } \\
\text { Dimensions }\end{array}$ & Respondents' & $\mathrm{N}$ & Mean & SD & MD & $\mathrm{t}$-values & Sig.(2-tailed) \\
\hline \multirow{2}{*}{ Tangibles } & Male & 180 & 3.818 & 0.590 & \multirow{2}{*}{0.318} & \multirow{2}{*}{1.660} & \multirow{2}{*}{0.099} \\
\hline & Female & 10 & 3.500 & 0.577 & & & \\
\hline \multirow{2}{*}{ Reliability } & Male & 180 & 3.652 & 0.599 & \multirow{2}{*}{0.292} & \multirow{2}{*}{1.521} & \multirow{2}{*}{0.130} \\
\hline & Female & 10 & 3.360 & 0.408 & & & \\
\hline \multirow{2}{*}{ Responsiveness } & Male & 180 & 3.480 & 0.554 & \multirow{2}{*}{0.505} & \multirow{2}{*}{2.199} & \multirow{2}{*}{$0.029 *$} \\
\hline & Female & 10 & 2.975 & 0.551 & & & \\
\hline \multirow{2}{*}{ Assurance } & Male & 180 & 3.888 & 0.441 & \multirow{2}{*}{0.688} & \multirow{2}{*}{3.316} & \multirow{2}{*}{$0.001 *$} \\
\hline & Female & 10 & 3.200 & 0.402 & & & \\
\hline \multirow{2}{*}{ Empathy } & Male & 180 & 3.592 & 0.592 & \multirow{2}{*}{0.032} & \multirow{2}{*}{0.169} & \multirow{2}{*}{0.866} \\
\hline & Female & 10 & 3.560 & 0.478 & & & \\
\hline
\end{tabular}

$* \mathrm{p}<0.05$

Table; 6 Independent Samples $t$-Test for comparison of Service Quality Dimensions by Gender (Employees)

\begin{tabular}{|c|c|c|c|c|c|c|c|}
\hline $\begin{array}{c}\text { S.Q } \\
\text { Dimensions }\end{array}$ & Respondents' & $\mathrm{N}$ & Mean & SD & MD & $\mathrm{t}$-values & Sig.(2-tailed) \\
\hline \multirow{2}{*}{ Tangibles } & Male & 68 & 4.202 & 0.514 & \multirow{2}{*}{-0.136} & \multirow{2}{*}{-0.852} & \multirow{2}{*}{0.397} \\
\hline & Female & 17 & 4.338 & 0.467 & & & \\
\hline \multirow{2}{*}{ Reliability } & Male & 68 & 4.255 & 0.463 & \multirow{2}{*}{0.020} & \multirow{2}{*}{0.145} & \multirow{2}{*}{0.885} \\
\hline & Female & 17 & 4.235 & 0.293 & & & \\
\hline \multirow{2}{*}{ Responsiveness } & Male & 68 & 4.209 & 0.417 & \multirow{2}{*}{-0.055} & \multirow{2}{*}{-0.307} & \multirow{2}{*}{0.759} \\
\hline & Female & 17 & 4.264 & 0.347 & & & \\
\hline \multirow{2}{*}{ Assurance } & Male & 68 & 4.180 & 0.373 & \multirow{2}{*}{-0.025} & \multirow{2}{*}{-0.144} & \multirow{2}{*}{0.886} \\
\hline & Female & 17 & 4.205 & 0.287 & & & \\
\hline \multirow{2}{*}{ Empathy } & Male & 68 & 4.188 & 0.431 & \multirow{2}{*}{0.023} & \multirow{2}{*}{0.137} & \multirow{2}{*}{0.891} \\
\hline & Female & 17 & 4.164 & 0.347 & & & \\
\hline
\end{tabular}

\section{Findings}

This research was aimed at assessing Pakistani banks service quality attitude by customers' and employees' acuities. Findings revealed that majority of the customers' were male (94.7\%), most of the customers fall in the age category of $21-30$ years $(55.8 \%)$, affiliation of customers with their banks depicts that majority was affiliated from $0-5$ years $(56.84 \%)$, followed by $6-10$ years $(28.94 \%)$, and most of the customers operate PLs account (50.5\%) with their banks, followed by current account, (43.2\%).

Employees' demographics showed that most of the employees are male (80\%), falling majority in the age category of 21- 30 years (56.5\%), followed by $31-40$ years (25.9\%), Majority have $0-5$ years banking experience (48.2\%), followed by $6-10$ years $(21.2 \%)$. Majority of the employees were master degree qualified, $(83.5 \%)$, followed by graduation $(15.3 \%)$.

Independent samples t-test of the respondents revealed that in tangibles dimension of service quality customers mean is 3.801 and employees mean is 4.229 , which shows significance difference in the perceptions of both the respondents. Reliability dimensions depict that customers mean is 3.636, and employees mean on the same dimension is 4.251 , in responsiveness customers mean is 3.453 , on the contrary employees mean is 4.220 , in assurance dimension of service quality, customers mean is 3.852 , employees mean is 4.185 , while in empathy dimension customers mean is 3.590 , but employees mean is 4.183 . Hence, it is clear that in all the dimensions of service quality as perceived by customers and employees of Pakistani banks, significant difference was found, which indicates certain picture of the actual performance of banks employees of Pakistani banks.

While analysis of service quality dimension, by gender spilt only in responsiveness, and assurance difference was found, in all other dimension, no significant difference of opinion was found; an interesting finding revealed here is that females'customers of Pakistani banks, are very low, as compared to male customers. By analyzing gender in employees' perspective, no significant difference was found in their perceptions, in all the dimensions of service quality of Pakistani banks. 


\section{Conclusion and Discussion}

Service quality, a measure of organizational excellence and customer satisfaction, is a prominent area of research especially in the services sector. The purpose of this study was to assess perceptions of Pakistani banks customers and employees in order to explore current state of service quality as perceived by both the parties, one who delivers it, other who got it. The difference in the mean scores of service quality dimensions is actually the grey area which banks needs to cover it. This research persuaded three research questions. First, was to know the perceptions of employees' and customers', in terms of tangibles, reliability, responsiveness, assurance, and empathy as sub-scales of service quality.

Perceptions assessment to measure service quality is supported and used this methodology in literature by many researchers, like ali et al., [7], used this approach and investigated the perceptions of branch managers, employees and customers of commercial banks in Pakistan and banks, should improve employees' related attributes in order to maintain competitive edge [30], perceptions were also found very important as there is a high customers involvement in the routine operation of banks [31].Second, research question was to compare the perceptions of both the respondents, in order to know the difference. Difference as stated above in table 3, in all the dimensions of service quality showed the exact picture of banks initiatives of Pakistani banks, findings are also supported by [7], significant difference was found among perceptions of managers, employees, and customers. Service quality and customer satisfaction was also correlated positively, as conducted by Ibraheem et al., [26, 31]. Third, research question was to know the significant difference of opinion in terms of back ground variables of the study. In all the demographics, no significant difference of opinion was found in the opinion of male, and female customers, and employees of Pakistani banks.

Consequently, literature of service quality in banking sector, keenly focused on strong relationship of service quality and customers satisfaction, like [1], explored customer satisfaction of banks, and revealed high association between the both, a comparative study on service quality and customer satisfaction conducted by malik [40], revealed that on various parameters of service quality, various services offered, customer satisfaction has significant implication by the part of public and private banks in India. Banks role in the development of any economy cannot be denied, as biggest sector of financial providers in all around the world, also in Pakistan. This study was an attempt to describe the difference of customers and employees of banks in terms of service quality measures. Banks should focus on customer oriented service quality initiatives in order to survive in the financial market as competition is expanding day by day, new challenges are approaching. Employees' training regarding service quality along with strategic measure are recommended to banks to reduce the gap of perceptions between employees and customers because service quality is considered an integral part of strategic focus of contemporary business.

\section{References}

[1] H. Sihombing, P. Chidambaram, and K. Rassiah, An Analysis of the Customer Satisfaction: A Case Study of Bank Service, International Journal of Application or Innovation in Engineering \& Management, 1(2), 2012, 33-43.

[2] EW. Anderson, C. Fornell, and DR. Lehmann, Customer satisfaction, market share, and profitability: findings from Sweden, Journal of Marketing, 58(July), 1994, 53-66.

[3] A. Kader MAA, N. Mohd K, Measuring perceived quality in Qatri Islamic Banks, J. International Business and Entrepreneurship Development, 4(1/2), 2009, 90-106.

[4] J. Akhtar, Determinants of Service Quality and Their Relationship with Behavioural Outcomes: Empirical Study of the Private Commercial Banks in Bangladesh, International Journal of Business and Management, 6(11), 2011, 146-156.

[5] Levesque. T, McDoughall, and G. HG, Determinants of customer satisfaction in retail banking, International Journal of Bank Marketing, 1996, 12-20

[6] Parasuraman, A., Zeithaml, V. A., \& Berry, L. L, SERVQUAL: A Multiple-Item Scale Measuring Consumer Perceptions of Service Quality. Journal of Retailing, 64(1),1988, 12-40.

[7] S. Ali R, S. Aziz, Z, S. Abir, H N, and A. Ali, Investigating Service Quality Initiatives of Pakistani Commercial Banks, International Business Research , 5(3), 2012, 107-113.

[8] S. Saraswathi, Perception of Customers on the Performance of the Private Banks - A Study with SERVQUAL, International Journal of Management \& Business Studies, 1(3), 2011, 95-99.

[9] Parasuraman, A., Berry, L. L., \&Zeithaml, V. A, Refinement and Reassessment of the SERVQUAL Scale.Journal of Retailing, 67(4), 1991, 420-450.

[10] Parasuraman, A., Berry, L. L., \&Zeithaml, V. A, Understanding Customer Expectations of Service.MIT Sloan Management Review, $1991 b, 39-48$

[11] Parasuraman, A., Zeithaml, V. A., \& Berry, L. L., A Conceptual Model of Service Quality and its Implications for Future Research. Journal of Marketing, 49(4), 1985, 41-50.

[12] Parasuraman, A., Zeithaml, V. A., \&Malhotra, A., E-S-QUAL A Multiple-Item Scale for Assessing Electronic Service Quality. Journal of Service Research, 7(3), 2005, 213-233.

[13] Powell, T.C., Total Quality Management as competitive advantage: A Review and Empirical Study, Strategic Management Journal, $16(2), 1995,15-37$

[14] Ruyter, de, K. and J.M.M. Bloemer, Customer loyalty in extended service settings: the interaction between satisfaction, value attainment and positive mood, International Journal of Services Industry Management, 1998, 321-336.

[15] S. Fatima H.G, M. Edwin G., Impact of service Quality in Commercial banks on the Customers Satisfaction: An Empirical Study, International Journal of Multidisciplinary Research, 1(6), 2011, 19-37.

[16] Crosby, P.B., Quality is Free: The Art of Making Quality Certain (Mc-Graw-Hill, New York, 1979). 
[17] Ramaswamy, R., Design and Management of Service Processes: Keeping Customers for Life, (Reading, MA: Addison-Wesley Publishing Co., 1996).

[18] Yong, J. K., A multidimensional and hierarchical model of service quality in the participant sport industry. doctoraldiss., The Ohio State University. 2000.

[19] Deighton, J.,The consumption of performance. Journal of Consumer Research, 19(12), 1992, 362-372.

[20] Gronroos, C., A service quality model and its marketing implications. European Journal of Marketing, 18, 1984, 36-44.

[21] C. Ming Ch, C. Tsu C, and C. Hsien H, A Review of Service Quality in Corporate and Recreational Sport/Fitness Programs, The Sport Journal-United States Sports Academy, 15, 2012.

[22] Reichheld, F. Ford and Sasser, E.W., Zero Defections: Quality comes to service. Harvard Business Review, September-October, 1990, 105-111.

[23] Ravichandran, K. Prabhakaran, S. and Kumar, S.A., Application of Servqual Model on Measuring Service Quality: A Bayesian Approach, Enterprise Risk Management, 1(1), 2010.

[24] Wisniewski, M., Using SERVQUAL to assess customer satisfaction with public sector services, Managing Service Quality, 11(6), 2000, 380-388.

[25] M. Mizenur R, Md. Abdullah, and A. Rahman, Measuring Service Quality using SERVQUAL Model: A Study on PCBs (Private Commercial Banks) in Bangladesh, Business Management Dynamics, 1(1), 2011, 01-11.

[26] S. IbraheemS.Al, R. M. Alhamali, and S. Abdullah A., Banking Service Quality by Commercials Banks and Customer Satisfaction, American Journal of Scientific Research, 27, 2011, 68-83.

[27] N. Minh T, Effects of Service Quality and Price Fairness on students Satisfaction, International Journal of Business and Social Sciences, 3(19), 2012, 132-150.

[28] A. Ahmad, K.-ur-Rehman, and N. Safwan, Comparative study of Islamic and Conventional banking in Pakistan based on customer satisfaction, African Journal of Business Management, 5(5), 2011, 1768-1773.

[29] S. Islam, and Md. Borak. Ali, Measuring Service Quality of Banks: An Empirical Study, Research Journal of Finance and Accounting, 2(4), 2011, 74-85.

[30] M. Brahmbhatt, and D. Panelia, An Assessment of Service Quality in Banks, Global Management Review, 2(4), 2008, 37-41.

[31] I. MohdTahir, and N. Mazlina A.B, Service Quality Gap and Customers' Satisfaction of Commercial Banks in Malaysia, International Review of Business Research Papers, 3(4), 2007, 327-336.

[32] K. Omar S, Interrelations between Service Quality Attributes, Customer Satisfaction and Customer Loyalty in the Retail Banking Sector in Bangladesh, International Journal of Business and Management, 6(3), 2011, 12-36.

[33] M. Long, and C. McMellon, Exploring determinants of retail service quality on the internet, Journal of Service Marketing, 18(1), 2004, 78-90.

[34] M. Imran, S. Abdul S.and R. Masood, Awareness Level of Islamic Banking in Pakistan's Two Largest Cities,Journal of Managerial Sciences, 5(1), 1-20.

[35] H. -ur-Rehman, and S. Ahmed, An Empirical Analysis of the Determinants of Bank Selection in Pakistan,Pakistan Economics and Social Review, 46(2), 2008, 147-160.

[36] N. Jabnoun, and H. A. Hassan Al-T., Measuring perceived service quality at UAE commercial banks, International Journal of Quality \& Reliability Management, 20(4), 2003, 458-472.

[37] E. Duncan, and G. Elliott, Customer service quality and financial performance among Australian retail financial institutions, Journal of Financial Services Marketing, 7, 2002, 25-41.

[38] T. Wang, and P. Ji, Understanding customer needs through quantitative analysis of Kano's model, International Journal of Quality \& Reliability Management, 27(2), 2010, 173-184.

[39] S. Ali Raza, and S.Abir H.N, Quality Of Pakistani University Graduates As Perceived By Employers: Implications For Faculty Development, Journal of Quality and Technology Management, 7(1), 2011, 57-72.

[40] G. Malik, A comparative study on the service quality and customer satisfaction among private and public banks in India, Pacific Business Review International, 4(3), 2012, 51-64. 